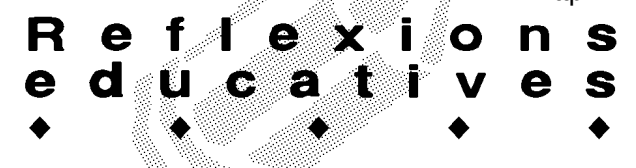

\title{
APORTACIONS DE L'EXPERIÈNCIA MUSICAL I EL MOVIMENT A L'EDUCACIÓ
}

\author{
María Ángeles Bermell Corral. Àrea de Didàctica de l'Expressió Musical. Universitat de València
}

La responsabilitat en la formació del professorat sempre serà un tema atractiu per als investigadors de l'educació. En aquests moments hi ha respostes a les limitacions de l'ensenyament tradicional, però hi ha altres àrees de coneixement amb experiències pràctiques que no es podran reforçar a l'escola per manca de disponibilitat horària, i això suposa un dèficit respecte a les necessitats del món infantil. La didàctica de l'expressió musical aporta coneixements interrelacionats amb habilitats i actituds, que donen lloc a una formació en competències. Això fa que el professor especialista en música, a més a més, pugui estimular un seguit de processos i capacitats mitjançant les activitats musicals. Tal i com es troba actualment aquesta especialitat, podrem justificarla mitjançant màsters. Mentrestant, avancem estudis que confirmen la importància de la vivència de la música conjuntament amb el moviment, des de les edats més primerenques.

\section{Introducció}

L'aplicació de les bases neuropsicològiques a l'aprenentatge de l'educació musical-dansa, conjuntament amb les didàctiques, té una influència molt important dins dels processos cognitius. I s'ha demostrat que l'atenció, factor que condiciona l'aprenentatge, es pot estimular mitjançant estratègies educatives musicals, on la imitació dels alumnes condueix puntualment a l'observació constant del professor. Aquest fet impedeix factors distractors, mentre que s'augmenten els nivells d'atenció-concentració i la seva posada en acció a través de tasques d'experiència compartides.

En aquest treball es pretén, des de l'experiència docent en la formació del professorat i en la intervenció amb nens amb necessitats educatives especials, generar expectatives d'investigació musical i reinvertir-les en el camp de l'educació, i informar d'altres investigacions recents a favor de les troballes relacionades entre la música i el cervell.

\section{Les últimes investigacions}

La música és tan antiga com l'ésser humà, i segons el seu tractament i finalitat, pot activar els mecanismes neuronals més profunds, modificar certs processos, millo- rar l'estat d'ànim, instaurar una organització motora, etc., com al llarg d'aquest estudi demostrarem.

L'experiència de la música no només és una experiència agradable, sinó que el seu poder evocador supera qualsevol altra sensació, a causa del timbre, de la melodia, del ritme, les dimensions del qual produeixen canvis bilaterals en l'estructura temporal (CACLIN et al., 2005), en el lòbul temporal superior $i$ una activitat lateralitzada dreta en el solc temporal superior (WARREN et al., 2005), etc. A aquests efectes hi hem d'unir, a més a més, que la seqüència de sons ordenats a través del temps, amb silencis i diferents ritmes, provoca reaccions emocionals. Sempre ha estat la companya lligada a la vida de les persones, i el compromís que adquireixen voluntàriament per gaudir de la música repercutirà en el seu futur.

La producció de la música genera una varietat de tasques com tocar instruments, cantar peces de memòria, improvisar, dansar, el processament cerebral del qual ha de combinar el desenvolupament i la integració de programes motors complexos, aixecats a uns nivells de competència en tasques visoespacials, seqüencials $i$ propioceptives amb un determinat temps per a les tasques motrius concretes més específiques, com la motricitat fina. Així, la producció musical inclou un nou subsistema de processament que converteix el programa visual en musical: llegim i cantem a primera vista (CAPPELLETI et al., 2000), cantem i toquem -component motor(PERETZ i COLTHEART, 2003), etc. És difícil pensar en un dia en el qual no escoltem una sola nota. Per això podem comprovar que la música estimula cada persona de forma dinàmica en el seu propi desenvolupament $i$ canvi. S'ha relacionat la dedicació a la música amb l'execució de determinats tipus de tasques cognitives en un programa d'intervenció (BERMELL, 2004), incrementant-se l'atenció així com l'autoestima a causa de l'execució de tasques sensoriomotores en grup. Per tant, agrupa les persones amb el propòsit de funcionar ordenadament i proporcionar un desenvolupament estructurat de components sensorials, motors, emocionals i socials. D'aquesta forma podem recórrer a les diferents aplicacions teòrico-pràctiques en l'educació infantil i primària, que es resoldrien amb les següents propostes: 


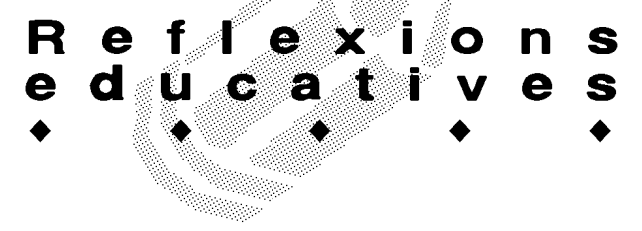

a) Estratègies educatives.

b) Recursos psicodidàctics amb diagnòstic individual/ grupal.

c) Programes d'intervenció per a tota l'aula.

\section{La música i l'educació}

L'evolució en l'àmbit educatiu, conjuntament amb les investigacions en el camp musical, ha donat lloc a altres camps que garanteixen la consecució d'uns objectius. Si es valorés el sistema d'ensenyament des d'una perspectiva neuropsicològica, arribaríem a la conclusió que el nen rep un ensenyament profundament asimètric en relació amb les aptituds cognitives que allotgen ambdós hemisferis cerebrals, ja que l'hemisferi esquerre (HE, a partir d'ara) porta el control de les conductes verbals, mentre que l'hemisferi dret (HD, a partir d'ara) dirigeix les conductes no verbals i de comportament espacial.

Sabem que l'escola potencia fonamentalment les aptituds de tipus verbal i memorístic, que estan més relacionades amb la funcionalitat de l'hemisferi esquerre, i les matèries relatives a la funcionalitat de l'hemisferi dret (àrea d'expressió musical, plàstica i corporal) queden en detriment. D'aquesta manera, els triomfadors del sistema seran aquells que tinguin unes aptituds intel-lectives ben desenvolupades en el seu HE, és a dir, el nen amb bon funcionament verbal o numèric.

En termes d'aplicació neurològica, es desconeix la importància d'aquestes matèries i les seves finalitats educatives i terapèutiques, i malgrat que s'ha fet un gran avenç, no és suficient per a una educació amb funcions d'integració. L'ensenyança encara és profundament disharmònica, perquè la majoria de les tasques escolars potencien les capacitats relacionades amb l'HE. Seguim observant que quan un nen presenta lesions o disfuncions cerebrals de l'HE, les expectatives de fracàs escolar són molt més grans que quan la lesió o disfunció es localitza a l'HD. I en aquest últim cas els efectes poden arribar a passar desapercebuts dins de l'àmbit escolar, la qual cosa dóna lloc a una falta de desenvolupament harmònic neurofuncional des del primer dia de classe.

Per altra part, els investigadors de la universitat de Münster (Alemanya) han informat sobre el fet que les lliçons de música a la infantesa engrandeixen el cervell. L'àrea per a l'anàlisi de les notes musicals és un $25 \%$ més gran en els músics que en les persones que mai no van tocar un instrument. Les troballes suggereixen que l'àrea es va engrandint a través de la pràctica i l'experiència. L'estudi arrencava d'una comparació de persones, la professió de les quals era la música, amb un altre grup que no eren músics. La prova consistia a fer-los passar per una màquina cerebral magnètica dirigida cap a l'escorça auditiva, de manera que els sons poguessin processar-se. Les neurones eren sensibles a les diferents freqüències sonores, i aquelles que s'excitaven amb la mateixa freqüència tendien a agrupar-se en petites illes i formaven una espècie de mapa de freqüències sonores a l'escorça auditiva. Conclogueren que els músics usen més neurones per processar els sons a causa del seu entrenament, i que aquells músics amb oïda absoluta 0 relativa no presentaven diferències. També s'observà que l'increment en la resposta als sons fou el mateix per als intèrprets de piano, vent $o$ corda, tenint en compte que tots ells havien rebut una instrucció musical primerenca. Aquesta situació ens porta novament a reflexionar sobre la importància de l'asimetria cerebral $i$ els programes d'educació amb una baixa distribució d'hores per a l'experiència musical.

\section{L'evolució de l'ésser i la percepció sonora}

La música sempre ens acompanya, i l'experiència rítmica es troba a la nostra herència genètica des del moment de la concepció. El ritme és el fil conductor entre la mare i el no nascut. L'evolució del futur ésser dependrà dels òrgans, la finalitat dels quals serà la de desenvolupar nivells harmònics per constituir funcions fins al moment del naixement. Per aquesta raó els pares s'han d'ajudar per afavorir la comunicació amb el no nascut (escoltar música apropiada, cantar, moure's amb ritme, etc.), però a més de crear un ambient relaxant experimenten una transformació emocional mentre s'escolten certes peces musicals. Efectivament, es desenvolupa una resposta fisiològica que es produeix, és involuntària, i es caracteritza perquè la intensitat i la qualitat de resposta emocional ve determinada pel tipus de música i per l'individu que l'escolta (JUSLIN i SLOBODA, 2001).

Un cop nascut, per consolidar els reflexos i les capacitats, el nen necessita exercitar-los per mitjà de l'estimulació, on el so i el ritme es fan imprescindibles com a guia de processos, i cada activitat dependrà de l'ocasió que tingui per exercitar les seves capacitats. Aquestes capacitats el portaran a la formació de conductes noves mitjançant el desenvolupament d'esquemes. Com exercitar la pressió al prendre un sonall perquè, setmanes més tard, pugui consolidar aquesta acció tancant la mà més selectivament. Les característiques de l'objecte que agafa donaran lloc a noves conductes per adaptarse a dites característiques. Aquest procés lent i continuat li anirà permetent l'assimilació i maduració per respondre al món que l'envolta.

Ens hem trobat que el fet que un nen arrossegui bloquejos a nivell sensorial i motor dóna lloc a certes disfuncions que segurament tindran repercussions en la seva vida. Les alteracions del llenguatge, de l'escriptura i la lectura, tenen el seu origen en dificultats motrius i, 


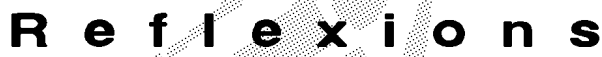 \\ e d u a a ti ve s}

per tant, rítmiques. Expressar, i com a consegüent intel-lectualitzar, és fruit d'experiències viscudes des del més profund del nostre ésser, que sustentem amb el cos i la ment, com el ritme i el moviment, que estimulem al treballar amb percussions corporals.

El desenvolupament de les percussions i el moviment, cal accionar-lo i dirigir-lo tenint present que la conducta ha estat evidenciada, descoberta, per ser estimulada gràcies al desenvolupament del moviment i a les activitats amb percussions, segons la necessitat dels casos. La comunicació, el diàleg i l'expressió a través del tacte formaran part del sentir, comprendre i conèixer, i donaran Iloc al desenvolupament del nen.

Com assenyala Rodríguez (1994), hem de ser conscients que, segons Piaget, només un petit nombre de reflexos tenen un origen genètic mentre que la majoria de les reaccions psicològiques tenen una base morfològica cerebral, que s'estructura d'acord amb la interacció entre l'organisme i el medi ambient. El desenvolupament neuronal té una cronologia bastant precisa, i requereix el pas progressiu per etapes diferents. El professor de música ha de presentar una optimització del material d'aprenentatge amb diversos procediments, amb dos objectius: a) estimulació per manca de maduració de processos, i b) estimulació per a l'ensenyança-aprenentatge perquè així pugui ser assimilat pels alumnes en funció del desenvolupament de les capacitats intel-lectuals de cadascun. També cal plantejar-se que aquelles experiències que es donen amb una precocitat excessiva puguin causar alteracions neuronals, a causa del desequilibri entre l'estímul sensorial i l'absència d'estructures neurològiques aptes per a rebre aquesta informació.

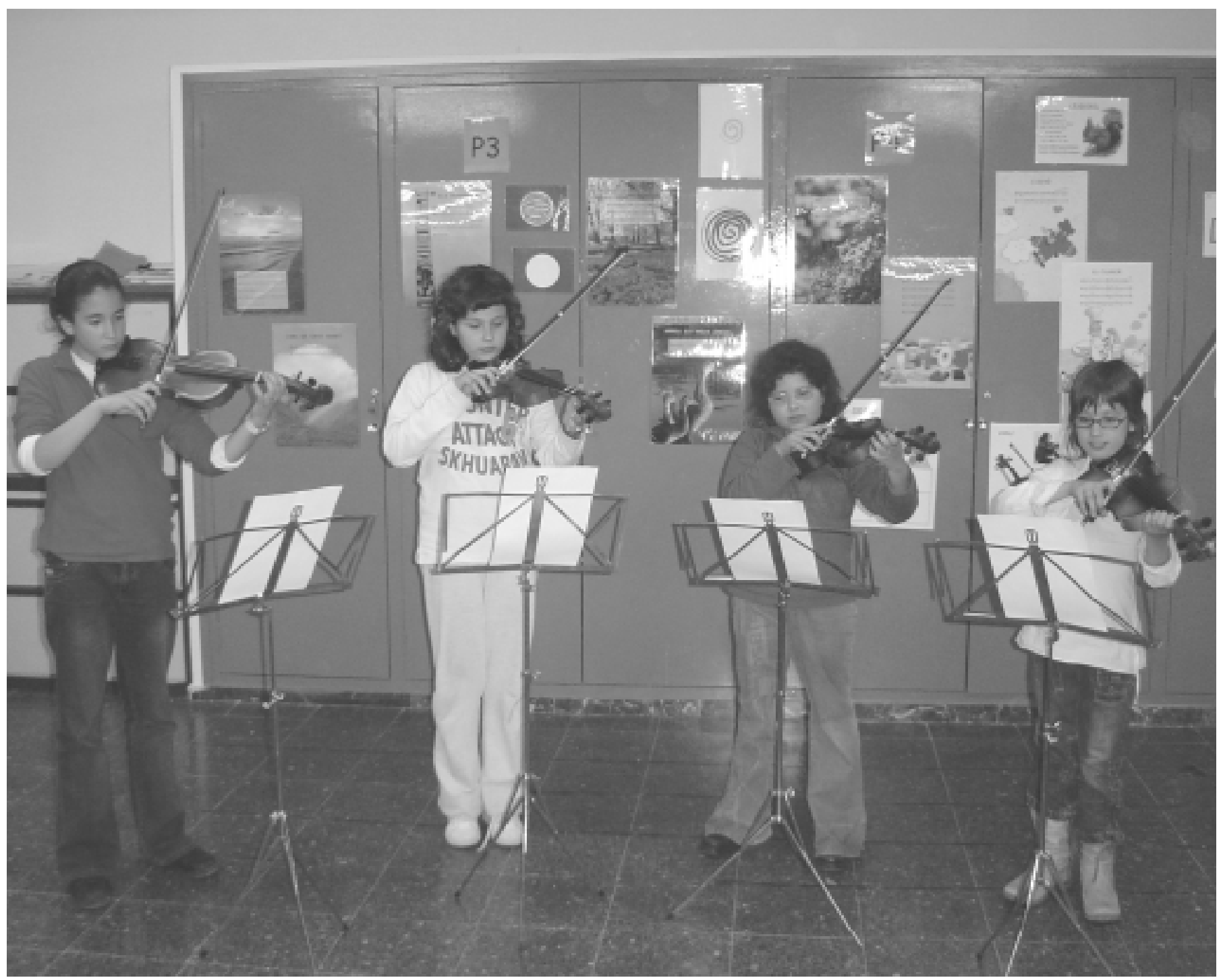




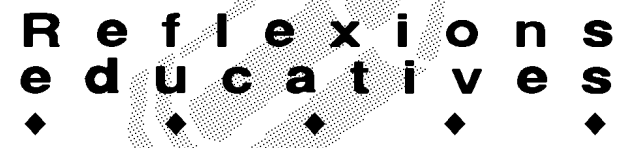

D'aquesta manera, les tasques de música i moviment es converteixen en estimuladores dels cinc sentits, ja que ofereixen una intensa relació amb el sentir i el món exterior. Desperten i potencien el procés de les facultats cognitives, perquè l'home coneix el món que l'envolta mitjançant els sentits, i dins d'ells, l'experiència sensorial: l'oïda i el moviment formen part de la informació més elemental del nostre medi perquè el cervell pugui organitzar-se des del naixement. Així, els sentits són els que ens proporcionen el material bàsic del que ha de ser la nostra intel-ligència. Són moltes les investigacions en l'àmbit musical que aporten línies directrius per al seu ús i investigació, i que es resumeixen en un seguit de finalitats de l'educació musical:

a) Des de l'embaràs amb el mètode First Star.

b) Programes d'estimulació primerenca.

c) A l'educació, amb programes d'intervenció per als trastorns del desenvolupament i l'aprenentatge.

d) Medicina preventiva, programes de conductes rítmiques.

e) Camp terapèutic, aplicació de la música a diferents problemes: estrès, ansietat, llenguatge, educació especial, geriatria, etc.

f) Com a analgèsic, programes de relaxació, selecció de melodies, etc.

\section{Bases neuropsicològiques de l'aprenentatge musical i el moviment}

Sabem que per a desenvolupar l'aprenentatge en l'ésser humà es necessita l'estimulació de capacitats, i aquestes capacitats requereixen la incorporació immediata i constant d'exercicis sobre les activitats innates del cervell. Tant unes activitats com les altres necessiten el funcionament del sistema nerviós; per tant podem dir que l'aprenentatge és el motor insubstituïble per ajudar a accionar aquest sistema (FLOREZ, 1999), i per portar a terme l'aprenentatge ens trobem amb formes diferents de desenvolupament.

Aquestes formes de desenvolupament vindrien donades per l'estimulació de capacitats a través del tractament manual/motor i del raonament. En el cas de la intervenció de la música i el moviment, es requereixen ambdues formes diferents per la ubicació dels elements constitutius de la música -ritme, melodia i harmonia, que es troben en ambdós hemisferis cerebrals (DESPINS, 1989), que es manifesta amb la posada en acció dels processos cognitius dels quals la base és el sistema nerviós central, estructura del cervell i cerebel. Per tant, aquesta intervenció estimula aspectes neuropsicològics, cognitius i de personalitat.

\section{Tractament de l'educació musical-moviment com a àrea específica}

L'estimulació obtinguda per l'aprenentatge activa els mecanismes cerebrals iniciant-se amb la percepcióatenció-memòria. Aquest procés necessita i persegueix els següents passos: recollir la informació, retenir-la, accedir, evocar i processar. Des de l'acció de la músicamoviment analitzem els objectius i els classifiquem en els blocs de contingut de la figura 1.

L'objectiu general del bloc de contingut del ritme i moviment requereix que l'alumne percebi el ritme-moviment

\section{ESTÍMULS}

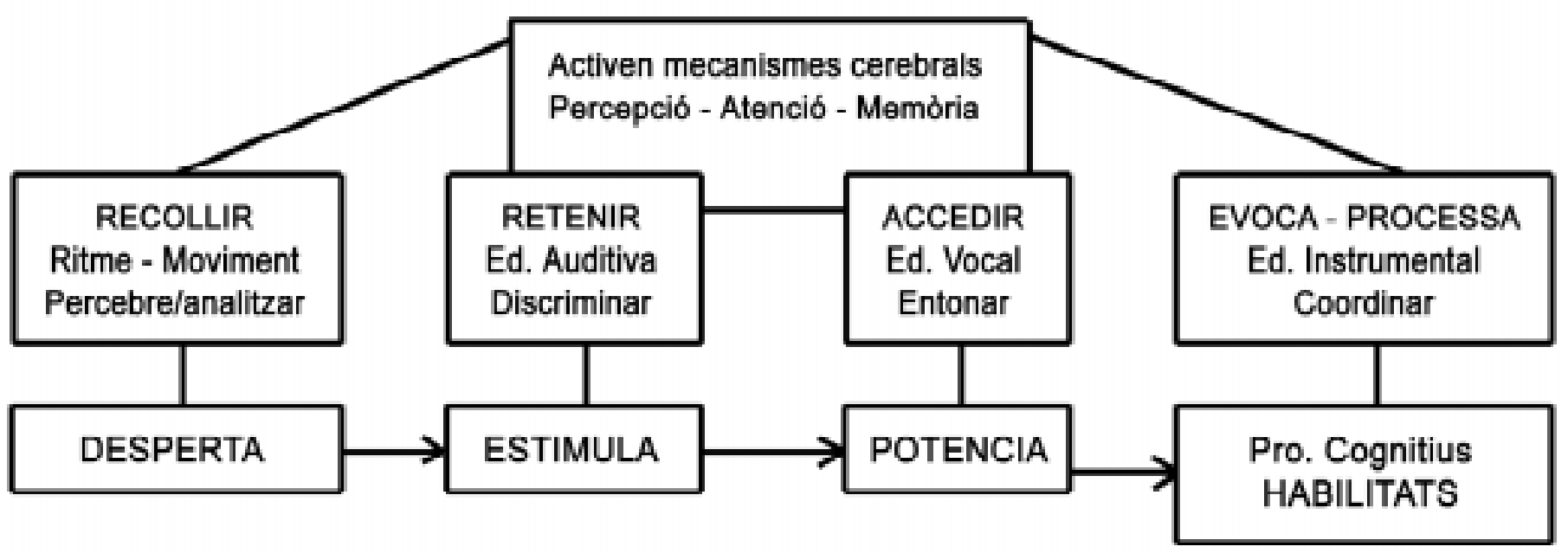

Figura 1. Estimulació d’àrees cerebrals mitjançant la música. 


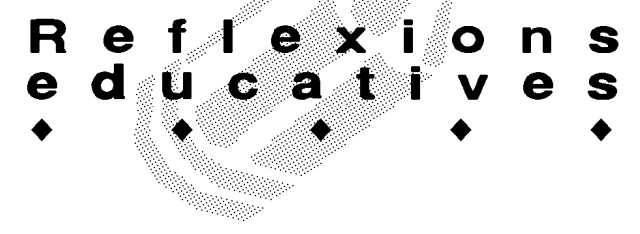

per a la seva anàlisi posterior, de manera que hagi de recollir aquesta informació i analitzar-la, la qual cosa el portarà a despertar unes vivències. Que a partir d'un exemple senzill com caminar, pugui, a més a més, picar de mans, i això doni lloc a una accentuació forta amb el peu esquerre, i l'accent feble amb el peu dret, de forma que sincronitzi ambdues tasques. Aquesta experiència desperta les seves capacitats, i al professor li permet l'observació contínua i la desitjada pe poder intervenir i ajudar.

El segon pas -retenir-ens porta al bloc de contingut d'educació auditiva, l'objectiu de la qual és discriminar les qualitats del so, és a dir, si treballem la tonalitat, hi ha una diferència entre els sons aguts i greus que tots poden apreciar. Pel que fa al timbre, no és el mateix el so d'un instrument de vent metall, com pot ser la trompeta, que el del piano, que és un instrument de corda percudida, etc. Totes aquestes tasques l'ajudaran a retenir la informació de forma gratificant, per la qual cosa diem que les seves capacitats són estimulades en l'ésser capaç de discriminar.

El tercer pas -accedir- apunta al bloc d'educació vocal, la finalitat del qual és donar la correcta altura a cada so de l'escala, dir el nom de la nota fent servir el sistema Kodály (visualitzant el so); per tant es potencien aquestes capacitats. Finalment, ens trobem amb l'evocació i la seva posada en marxa amb el processament de la informació, la qual cosa ens porta al bloc d'experiència instrumental. El nen ha d'evocar i processar tota la informació dels passos anteriors per coordinar: l'anàlisi del ritme amb el moviment, la discriminació de l'educació auditiva, l'entonació de l'educació vocal i expressar la música mitjançant els instruments. Les activitats amb la música i el moviment no desenvolupen només els processos cognitius, sinó a més a més les habilitats (BERMELL, 2001).

\section{Aplicació i aportacions de la música i moviment a la teràpia}

Tots sabem que l'aprenentatge és el motor insubstituïble per al desenvolupament, i exigeix que el sistema nerviós sigui modificat constantment pels estímuls exteriors o ambientals gràcies a la propietat de plasticitat del cervell (RODRÍGUEZ, 1994). Quan es treballa l'atenció i la memòria, s'està exercitant la base fonamental de l'aprenentatge i de l'activitat cognitiva, però a més, aquest coneixement és modulat de forma intensa per l'activitat emocional (FLOREZ, 1999), per la qual cosa podem dir que quan estimulem els processos cognitius amb la músicamoviment, a més enfortim i coordinem els moviments, perquè s'ajuda a extreure tensions per modificar conductes.

Per portar a terme aquesta intervenció ens trobem amb dues línies d'actuació: la primera és mitjançant l'escolta musical, on les últimes investigacions (BELIN et al., 2000) confirmen que quan el pacient ha estat sotmès a una tomografia d'emissió de positrons mentre escoltava música, es va observar com s'activaven certes àrees i a més es delimitava el camp (quan al pacient se'l sotmetia a la prova pet, es detectà l'activació de certes àrees amb l'escolta musical, la qual cosa va permetre a l'equip de neurologia detectar amb major exactitud l'àrea cerebral a intervenir), qüestions que anteriorment no s'havien pogut constatar quan el pacient no escoltava música. Això és degut al fet que el ritme, la melodia i l'harmonia es troben ubicats en els dos hemisferis cerebrals: el ritme en ambdós hemisferis, la melodia a l'hemisferi dret i l'harmonia a l'esquerre (DESPINS, 1989).

També sabem que el procés d'informació de l'hemisferi esquerre és simultani, i a l'hemisferi dret seqüencial; és a dir, un nen llegeix una paraula al primer cop de vista, i s'exercita l'HE, mentre que quan llegeix mitjançant els fonemes, exercita l'hemisferi dret. Amb la música succeeix el mateix, quan s'expressa un acord (tres o més sons simultanis) estem utilitzant l'HE; quan llegim una melodia, l'HD. Però a més, i en el cas dels pianistes, la melodia és escrita en clau de sol interpretada amb la mà dreta, i l'acompanyament en clau de fa, per la mà esquerra; és a dir, que utilitzem un procés de dualitat al llegir diferents pentagrames. Podem dir que existeix una major acció hemisfèrica gràcies a les diferents tasques de la música aconseguides (BENGTSSON et al., 2005). Una segona intervenció seria a través de l'experiència de l'aprenentatge musical que, com anem demostrant al llarg d'aquest estudi, ens trobem que existeixen majors connexions sinàptiques per a l'aprenentatge de la músicamoviment, però a més les investigacions ens demostren que existeix més estabilitat i permanència de la memòria (LIEGEOIS et al., 1998). Entenem, doncs, que des de la neuropsicologia l'objectiu principal del professor ha de ser programar tasques per activar una major connexió de les vies sinàptiques o xarxa de vies per mitjà de l'aprenentatge, que s'inicia amb l'educació dels sentits, és a dir, estimulant mitjançant la música i el moviment.

Aquests programes recullen les necessitats bàsiques per estimular una educació primerenca. I aquests estímuls, aplicats com a teràpia, ens porten a considerar els programes individuals per a les necessitats educatives. Per portar a terme la implementació de tasques hem de conèixer l'alumne/a atenent les següents pautes o fases de construcció:

a) Si existeix disfunció o lesió i el seu origen.

b) Si parla o no, i el nivell verbal així com el ritme de les seves paraules.

c) Quins moviments fa.

d) Quin és el seu ritme en general. 


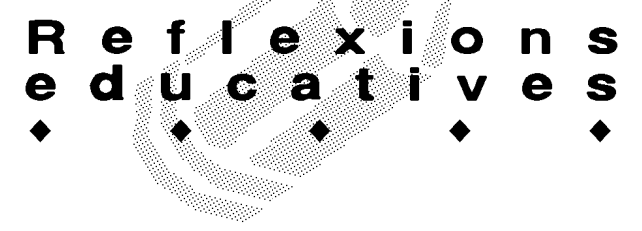

e) Quin és el ritme del seu moviment.

Partint dels blocs de contingut ja comentats, o a títol d'exemple senzill per a la seva aplicació al camp de la teràpia, dissenyem la següent cerca de respostes en el nen i el seguiment dels procediments:

- Formació rítmica i moviment: Percudir palmells al mateix temps que escolten el pandero.

- Educació auditiva: Improvisar amb pregunta-resposta (Jo em dic... I tu, com et dius?).

- Educació vocal: Mitjançant el sistema Kodály s'inicia la impostació de les vocals obertes.

- Educació instrumental: El tractament de baquetes recolza l'estimulació del tacte.

\section{Períodes i modes evolutius de la música}

La investigació a Latorre i Rocabert (1997) abasta des del naixement de l'infant i on la resposta motora apareix com una manipulació experimental de materials sonors, iniciant-se el procés de descobriment, que ha d'anar íntimament lligat al procés del ritme de la música per a una millor organització de l'àrea espacio-temporal. Així, estableix quatre períodes del desenvolupament musical, enfront de Swanwick (2000), que considera vuit modes evolutius per assolir el desenvolupament musical.

Els paràmetres que el mestre ha d'estimular, són:

1. Període d'experimentació (0 a 2 anys): Manipulació experimental de materials sonors.

2. Període d'estructures i pautes sonores (3 a 7 anys): Especulació sobre els sons vocals-musicals.

3. Període de les convencions de la producció musical (8 a 13 anys): Progressar i imitar l'adult en la interpretació.

4. Període d'expressió personal (a partir dels 14 anys): Utilitza la música per expressar les seves emocions.

Els paràmetres que el mestre ha d'estimular, segons Swanwick (2000), són:

1. Mode sensorial ( 0 a 3 anys): Els nens responen al timbre i a la intensitat.

2. Mode manipulatiu (4 a 5 anys): Interès pels instruments.

3. Mode d'expressivitat personal (5 a 6 anys): La seva expressivitat acompanya la música.

4. Mode vernacle ( 7 a 8 anys): Procés de producció de música convencional.

5. Mode especulatiu (9 a 11 anys): Adquireix cert domini musical i pot experimentar.

6. Mode idiomàtic (12 a 14 anys): La recerca de la identitat personal amb certs intèrprets.

7. Mode simbòlic (14 a 15 anys):Metacognició o capacitat per reflexionar sobre un mateix i sobre la pròpia experiència musical.
8. Mode sistemàtic (a partir dels 15 anys): Suposa el nivell màxim propi de les persones evolucionades, capaces de reflexionar i raonar sobre la seva pròpia experiència amb la música.

\section{Influència de la melodia en la memòria d'evocació}

Donada la simbiosi de l'atenció i la música, hem volgut fer un apartat de la memòria, ja que per al desenvolupament de l'atenció es requereix l'emmagatzemament dels sons per al seu reconeixement, i aquest sempre va guiat per certa afectivitat i personalitat de l'alumne.

La importància del factor afectiu a l'escola és força coneguda pels educadors. El mestre d'avui es troba, de vegades, que li és molt difícil captar certs alumnes perquè memoritzin. Aquesta situació implica que el docent accepti aquest sentiment de l'alumne, sigui positiu o negatiu, i que sigui urgent donar-li una sortida acceptable. Per tant, es dedueix que un estat psicològic favorable contribueix enormement a incrementar l'eficàcia de les regles mnemotècniques que convé observar en l'estudi de qualsevol matèria.

Els canvis es produeixen en l'ésser humà segons el seu desenvolupament, i malgrat que la memòria pugui ser operativa des del naixement, cal unes millores. Com podem ajudar?

Per estimular la memòria podem tenir en compte els següents punts:

- Durant el primer any de vida, les millores vindrien donades per la quantitat de temps que pot retenir un objecte (millora musical).

- La majoria de demostracions de memòria en els bebès es refereix només a uns pocs segons entre la presentació de l'estímul i la prova per al reconeixement d'aquest estímul. Per tant, aquests estudis mostren una memòria a molt curt termini.

- Quan el bebè es desenvolupa i recorda les seves experiències, augmenta de forma constant (els instruments infantils són més motivadors), i assoleix ben aviat nivells prou impressionants.

- Així, els nens més grans poden recordar més informació i més complexa que els de menor edat, $\mathrm{i}$ a més poden abstreure i recordar categories generals d'informació i no només estímuls específics.

La memòria del reconeixement és present des del naixement. Però la memòria d'evocació és considerablement més difícil d'estudiar en la infantesa que la de reconeixement, ja que els bebès no poden reproduir les respostes que s'utilitzen per estudiar l'evocació en subjectes de més edat; de fet no hi ha un consens clar sobre què podria fer un bebè que mostrés que evoca i, per tant, no hi ha consens sobre quan comença exactament l'evocació. 


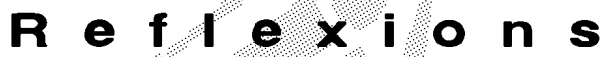 \\ e d u c a t i ves}

Sembla que l'evocació és present abans del final de la infantesa, com impliquen moltes de les formes del comportament del sisè estadi sensorio-motor de Piaget. Un bebè no podria mostrar una imitació diferida, per exemple, sense la capacitat de recordar un model no present, ni podria produir paraules adequadament sense algun tipus de capacitat per a l'evocació. Ara bé, el cant de la mare, pot ajudar el bebè a evocar? Fins on arriba la importància de les cançons de bressol?

\section{Estratègies de simulació}

La classe de música és altament rica en materials, que provoquen interès en els nens, començant pels instruments i el seu timbre específic fins al desenvolupament dels seus intervals, conduint-los a estats d'ànim, sense entrar en la producció del ritme. Són moltes i molt va- riades les activitats que es poden organitzar per crear hàbits d'escolta i com a conseqüència l'estimulació de l'atenció i la memòria. Intentarem donar un exemple global que permeti l'adaptació segons el nivell del nen per a cada bloc de contingut (BERMELL, 2001):

1. Caminar associant un peu a cada pols (formació rítmica i moviment).

2. Diferenciar instruments de percussió de so determinat o indeterminat amb l'opció de veure o no l'instrument (educació auditiva).

3. Imitar un so que ha emès el professor/a però dient al mateix temps el nom de la nota (educació vocal).

4. Escoltant el professor, interpretar rítmicament o melòdicament una estructura senzilla (educació instrumental).

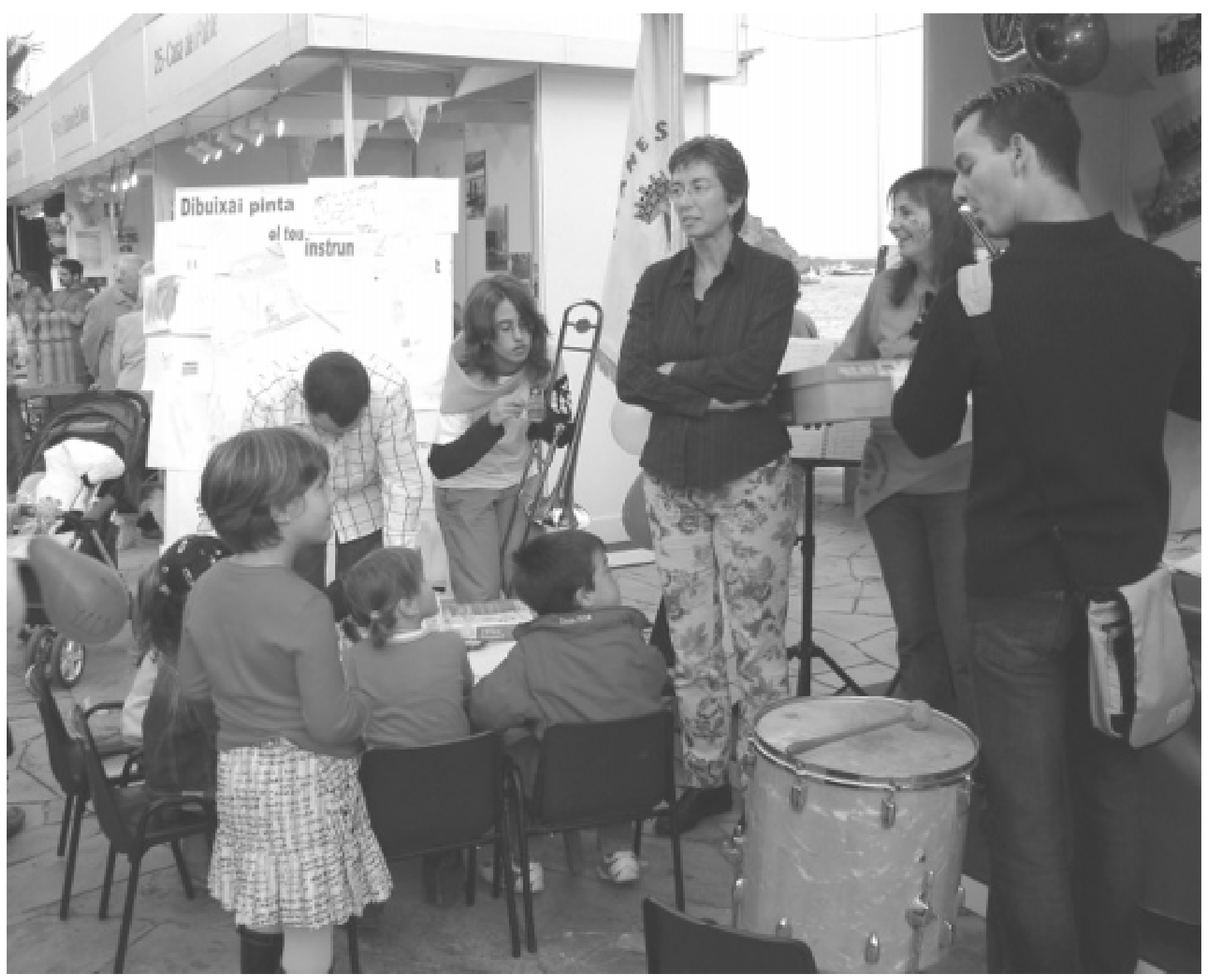




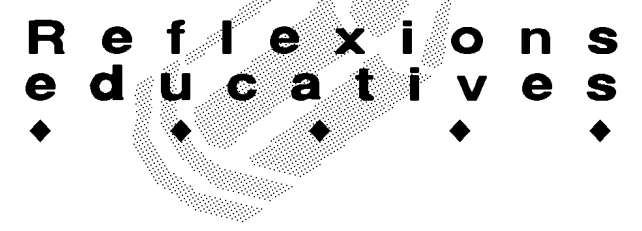

Si observem i dirigim l'atenció a l'element sonor, llevat de certes excepcions, podem supeditar l'audició mitjançant ordres per formar nens receptius (BIGAND, 2003), per la qual cosa recomanem des de l'escola maternal la utilització d'aquestes tasques portades a través del joc. Com a resultat, a la primària s'haurien d'orientar a crear hàbits, que al seu torn ajudarien a enfortir processos, $\mathrm{i}$ consegüentment a aïllar conductes inequívoques, com a conseqüència d'una correcta estimulació de l'atenció. És necessari que els monitors, professors i personal que treballa amb nens coneguin la predisposició musical que tenen els nens (TREHUB, 2001).

\section{Exemples d'activitats per a educació infantil}

1. Un tren. Estructura rítmica que acompanya la formació d'un grup de nens mentre fan una formació, adequant els seus passos al ritme i a la formació (educació rítmica).

2. Com una pilota. Tocar un arpegi, fer una volta sobre ell mateix i partir de nou en la mateixa direcció. Un acord simple, fer mitja volta; dos acords simples, una volta sencera; acord compost, canviar el sentit de la marxa (educació auditiva i espacial).

3. Banda d'ocells. Grup de tres, quatre, cinc, sis i set persones col-locades en diferents formes geomètriques. A cadascuna d'elles se li associa una nota. Quan se senti la nota interpretada per la flauta, l'alumne la imitarà desplaçant-se mentre entona la seva nota per passar al vèrtex que va en cap, de manera que els altres companys prendran altres llocs sense canviar-se les notes (atenció auditiva i adaptació espacial).

4. El mirall. Mentre s'escolta un adagi, les parelles han d'anar movent-se amb moviments que es complementin. És a dir, la primera persona fa un moviment amb el braç, per exemple, i el seu company repeteix el moviment, repeteix la primera, completa la segona, etc. Han d'anotar els passos, figures o conceptes que han desenvolupat. Quan se senti una palmellada, es canviaran (atenció visual, motriu i espacial).

5. Refilet: volar com un ocell. Arpegi: passes de gegant. Acord simple en el registre mitjà: caminar. Acord greu: caminar marxa enrere. Acord agut: caminar amb mitges puntes (atenció auditiva i motriu).

És molt important que els alumnes no tinguin vicis en els desplaçaments. És a dir, sempre es tendeix a formar cercles i no assumeixen la independència del desplaçament, i això causa involuntàriament indecisió i impediments per al desenvolupament de la lateralitat.

\section{Referències bibliogràfiques}

BELIN, P., ZATORRE, R. J., LAFAILLE, P., AHAD, P. i $\mathrm{PIKE}, \mathrm{B}$. Voice-selective areas in human auditory cortex. «Nature», 403 (2000) 309-312.

BENGTSSON, S. L., NAGY, Z., SKARE, S., FORSMAN, L., FORSSBERG, H. i ULLÉN, F. Extensive piano practicing has regionally specific effects on white matter development. «Nature Neuroscience», 8,9 (2005) 1148-1150.

BERMELL, M. A. Programa de intervención educativa. Libro del profesor. Rivera Editores. València. 2001.

BERMELL, M. A. Programa de intervención educativa. Cuaderno del alumno. Vol. 1, 2, 3. Rivera Editores. València. 2001.

BERMELL, M. A. Evaluación de un programa de intervención basado en la música-movimiento como optimizador del aprendizaje en la educación primaria. Tesi doctoral. Universitat de València. 2004.

BIGAND, E. More about the musical expertise of musically untrained listeners. «Annals of the New York Academy of Sciences», 999 (2003) 304-312.

CACLIN, A., et al. Acoustic correlatos of timbre space dimensions: a confirmatory study using synthetic tones. "Journal of the Acoustical Society of America», 118 (2005) 471-482.

CAPPELLETTI, M., WALEY-COHEN, H., BUTTERWORTH, B. I KOPELMAN, M. A selective loss of the ability to read and write music. «Neurocase», 6,4 (2000) 321-332.

DESPINS, J. P. La música y el cerebro. Edit. Gedisa, S.A. Barcelona. 1989.

FLOREZ, J. Bases neurobiológicas del aprendizaje. «Siglo Cero», 30 (1999) 9 -27.

JUSLIN, P. "Extensive piano practicing has regionally specific effects on white matter development". Dins SLOBODA, J. Music and Emotion: Theory and Research. Edit. Oxford University Press. 2001.

LATORRE, A. i ROCABERT, E. Psicología escolar, ámbito de intervención. Edit. Promolibro. Valencia. 1997.

LIEGEOIS-CHAUVEL, C., PERETZ, I., BABAÏ, M., LAGUITTON, V. i CHAUVEL, P. Contribution of different cortical areas in the temporal lobes to music processing. «Brain», 121 (1998) 1853-1867.

PERETZ, I. i COLTHEART, M. Modularity of music processing. «Nature Neuroscience», 6 (2003) 688-6991.

RODRIGUEZ, J. M. Mi cerebro y yo. Ediciones Temas de Hoy, S.A. Madrid. 1994.

SWANWICK, K. Música, pensamiento y educación. Edit. Morata, S.L. Madrid. 2000.

TREHUB, S. E. Musical predispositions in infancy. «Annals of the New York Academy of Sciences», 930 (2001) 1-16.

WARREN, J. D., JENNINGS, A. R. i GRIFFITHS, T. D. Analysis of the spectral envelope of sounds by the human brain. «Neuroimage», 24,4 (2005) 1052-1057. 